\title{
Tomasz Szczygiet
}

Uniwersytet Śląski, Katowice

tomasz.szczygiel@us.edu.pl

ORCID: https://orcid.org/0000-0002-7017-0000

\section{Problematyka przerywania ciąży jako zagadnienie kodyfikacyjne prawa karnego materialnego Polskiej Rzeczypospolitej Ludowej w latach 1956-1969}

http://dx.doi.org/10.12775/SIT.2021.015

\section{Wprowadzenie}

Przestępstwa $z$ kategorii przeciwko życiu i zdrowiu należą do historycznie najwcześniejszych, jeśli chodzi o ich typizację w ustawodawstwie. Jednym $z$ nich jest czyn polegający na przerywaniu ciąży, którego ocena karnoprawna zawsze wzbudzała wiele emocji. Dzieje się tak dlatego, że jakiekolwiek podejście do tej kwestii zawsze będzie prowadziło do konfliktu $z$ tym czy innym dobrem. Ustawodawca musi w tym przypadku rozważyć bardzo wiele racji, w tym tych o wymiarze ogólnym (względy populacyjne, społeczne), jak i indywidualnym (ochrona praw kobiety i życia nienarodzonego dziecka). Dochodzą do tego jeszcze względy medyczne, światopoglądowe, ideologiczne i religijne ${ }^{1}$.

${ }^{1}$ Szerzej zob. A. Czajkowska, O dopuszczalności przerywania ciąży. Ustawa 
Zadaniem niniejszej pracy jest ukazanie, jak z powyższym zagadnieniem próbował sobie radzić w Polsce socjalistyczny ustawodawca, którego zamiarem po wojnie było stworzenie nowego ustawodawstwa karnego.

\section{Stan prawny według Kodeksu karnego z 11 lipca 1932 r.}

Obowiązujący wciąż jeszcze w Polsce Ludowej po 1944 r. kodeks karny z 1932 r. ${ }^{2}$ regulował kwestię karnoprawnych skutków przerywania ciąży (tzw. spędzenie płodu) w art. 231-234 k.k. ${ }^{3}$ Stając $\mathrm{w}$ zasadzie na gruncie zakazu dokonywania aborcji, tak przez samą kobietę, jak i inną osobę (np. lekarza), ustanawiał jednak warunki bezkarności „spędzenia płodu”. Przedmiotem ochrony było życie płodu, a nie proces ciąży ${ }^{4}$. Podstawową przesłanką wyłączenia bezprawności było dokonanie aborcji przez lekarza. Kodeks wymieniał dwa przypadki, kiedy lekarz miał prawo przerwać ciąże. Pierwszy dotyczył względów zdrowotnych kobiety ciężarnej, drugi wskazywał na przestępcze pochodzenie ciąży (art. 233 k.k.) $)^{5}$.

Stosunek do tych przepisów w okresie do 1956 r. można podzielić na dwa wyraźne podokresy. Pierwszy, do 1955 r., charakteryzo-

z dnia 27 kwietnia 1956 r. i towarzyszace jej dyskusje, w: Kłopoty z seksem $w$ PRL. Rodzenie nie całkiem po ludzku, aborcja, choroby, odmienności, red. M. Kula, Warszawa 2012, s. 99-110.

${ }^{2}$ Dz.U. z 1932 r. Nr 60, poz. 571, dalej: k.k.

3 „Kobieta, która płód swój spędza lub pozwala na spędzenie go przez inną osobę, podlega karze aresztu do lat 3” (art. 231); „Kto za zgodą kobiety ciężarnej płód jej spędza lub jej przy tym udziela pomocy, podlega karze więzienia do lat 5” (art. 232); „Nie ma przestępstwa z art. 231 i 232, jeżeli zabieg był dokonany przez lekarza i przytem: a) był konieczny ze względu na zdrowie kobiety ciężarnej, albo b) ciąża była wynikiem przestępstwa, określonego w art. 203, 204, 205 lub 206” (art. 233); „Kto bez zgody kobiety ciężarnej płód jej spędza, podlega karze więzienia do lat 10" (art. 234).

4 M. Lipczyńska, Ochrona płodu w ustawie z 27 kwietnia 1956 r. i projekcie k.k., „Nowe Prawo” 1957, nr 1, s. 21.

5 J. Makarewicz, Kodeks karny z komentarzem, Lwów 1938 (reprint Wydaw. KUL 2012), s. 529-530. 
wał się poglądem o zbyt liberalnym charakterze przepisów dotyczących tego zagadnienia ${ }^{6}$. Szczególne emocje wywoływała kwestia „propagandy za ograniczeniem dzietności” oraz ścisłej kontroli i reglamentacji uprawnień lekarzy do przerywania ciąży ${ }^{7}$. Zaostrzenie polityki wobec aborcji dosadnie oddawało hasło: „Należy wyrobić u matek poczucie obowiązku i wykazać, że ona dla narodu ofiarę ponosić musi, choćby nawet miała to życiem przepłacić. Winna ona zrozumieć tę wyższą konieczność tak, jak pojmować ją musi żołnierz na froncie"8. Podnoszono również, że między prawem cywilnym a prawem karnym istniała trudna do wytłumaczenia sprzeczność. $Z$ jednej strony bowiem przepisy cywilnoprawne chroniły interesy dziecka poczętego w okresie przed urodzeniem (np. art. 29 przepisów ogólnych prawa cywilnego z 12 listopada 1946 r. ${ }^{9}$ oraz art. 5 $\S 2$ prawa spadkowego $z \quad 8$ października $1946 \mathrm{r}^{10}{ }^{10}$, $\mathrm{z}$ drugiej jednak przepisy Kodeksu karnego nie gwarantowały ochrony tych praw poprzez względną ochronę życia nasciturusa ${ }^{11}$.

Straty w ludziach wywołane II wojną światową uzasadniały niewątpliwie takie podejście. Niepokojące było to, że nasilało się zjawisko nielegalnych tzw. pokątnych poronień. Ich negatywny wpływ na zdrowie i życie matek oraz w konsekwencji populację powojennego kraju były oczywiste ${ }^{12}$. Co więcej, wraz ze wzrostem sztucznych

${ }^{6}$ Odpis z wyciągu z protokołu plenarnego posiedzenia Miejskiej Rady Narodowej w Raciborzu z dnia 28 kwietnia 1948 r. - Archiwum Akt Nowych (dalej: AAN), Ministerstwo Sprawiedliwości (dalej: MS), sygn. 285/1837); A. Czajkowska, O dopuszczalności przerywania ciąży. Ustawa z dnia 27 kwietnia 1956 r. i towarzyszące jej dyskusje, s. 136.

7 Odpis pisma dyrektora Departamentu Ustawodawczego Ministerstwa Sprawiedliwości z dnia 7 lipca 1948 r. do Biura Prawnego Rady Państwa ibidem.

${ }^{8}$ Cyt. za: B. Klich-Kluczewska, Rodzina, tabu i komunizm w Polsce 1956-1989, Kraków 2015, s. 239.

${ }^{9}$ Dz.U. z 1946 r. Nr 67, poz. 369.

${ }^{10}$ Dz.U. z 1946 r. Nr 60, poz. 328.

11 Pismo z dnia 18 września 1950 roku S. Chrempińskiego do Ministra Sprawiedliwości (AAN, MS, sygn. 285/1837).

12 A. Czyżewicz, Częstość poronień, „Polski Tygodnik Lekarski” 1950, nr 12, s. 451-453. 
poronień wyraźnie malała liczba porodów, które znacznie łatwiej poddawały się procesowi rejestracji ${ }^{13}$.

Były to więc wszystko zjawiska wielce niepokojące, dlatego też postulowano m.in., aby wykluczyć możliwość przerywania ciąży ze względu na jej przestępcze pochodzenie oraz zakazać dokonywania aborcji poza placówkami służby zdrowia ${ }^{14}$. Takie było przekonanie przede wszystkim części środowiska lekarskiego, niektórych wydawnictw prasowych, Stronnictwa Pracy oraz Kościoła katolickiego ${ }^{15}$. Brak $z$ kolei publikacji na ten temat w oficjalnym prawniczym periodyku Ministerstwa Sprawiedliwości, jakim był wówczas przede wszystkim „Demokratyczny Przegląd Prawniczy” i następnie „Nowe Prawo”, wskazywał z kolei albo na pewną obojętność władzy w tym zakresie, albo na chęć zachowywania pozorów, że nie ma problemu. Jest to tym bardziej zastanawiające, że przecież do 1955 r. w ZSRR obowiązywał całkowity zakaz aborcji ${ }^{16}$. Jak zdaje się sugerować Jerzy Sawicki, okres ten był najmniej przyjazny dyskusji na te tematy. Pomysł reformy w którąkolwiek ze stron był wówczas bardzo kontrowersyjny ${ }^{17}$.

Drugi okres w podejściu do przepisów antyaborcyjnych wyznacza data 1955, czego w kontekście dekretu z 23 listopada 1955 r. w ZSRR nie można uznać za wydarzenie przypadkowe ${ }^{18}$. Podobnie jak w ZSRR, tak i w Polsce Ludowej okresu postalinowskiego problemem już nie jest odbudowa populacji, a chęć przeciwdziałania negatywnym zjawiskom jej wzrastania. Pogląd na przepisy artykułów 231-234 k.k. ulega wówczas diametralnej zmianie. Ze zbyt

13 Ibidem, s. 454.

${ }^{14}$ S. Chrempiński, Projekt przepisów dotyczacych spędzenia płodu wraz z uzasadnieniem, s. 2-3 (AAN, MS, sygn. 285/1837).

${ }^{15}$ Ibidem.

${ }^{16}$ Dekretem z 23 listopada 1955 r. zniesiono w ZSRR zakaz przerywania ciąży, który obowiązywał od 1936 r. - cyt. za: H. Wolińska, Przerwanie ciąży $w$ świetle prawa karnego, Warszawa 1962, s. 19 (przypis nr 1).

17 J. Sawicki, Przedmowa, w: H. Wolińska, Przerwanie ciąży, s. 7.

18 A. Lityński, Prawo Rosji i ZSRR 1917-1991, czyli historia wszechzwiąkowego komunistycznego prawa (bolszewików). Krótki kurs, Warszawa 2012, s. 264 . 
liberalnych „stają się one” nazbyt restrykcyjne ${ }^{19}$. Między innymi to właśnie rzekomo zbyt przestarzałym i w praktyce „martwym” przepisom kodeksu karnego zaczęto przypisywać zjawisko rosnącej skali sztucznych poronień oraz ich negatywnych skutków w postaci śmierci matek ${ }^{20}$. Jak przekonywała Helena Danielak, powołując się na prof. Wiktora Grzywo-Dąbrowskiego, społeczeństwo przed wojną i po niej po prostu nie postrzegało sztucznych poronień za przestępstwo, co czyniło z obowiązujących przepisów martwe lub nieskuteczne rozwiązania prawne, ponieważ sędziowie byli podobnego zdania ${ }^{21}$. Problemem były pokątne aborcje, które jeżeli byłyby rzeczywiście ścigane, to - jak wskazuje Helena Danielak -, „co najmniej połowa kobiet figurowałaby w rejestrze skazanych”22.

Problem miał jednak wymiar także ideologicznie bardzo rażący, wskazywał bowiem - jak trafnie zauważył Zbigniew Kubec - na podział kobiet pod względem majątkowym, na te które mogły sobie pozwolić na aborcję przy udziale lekarza, oraz te, które ze względu na brak środków finansowych udawały się do pokątnych akuszerek i tzw. babek, często ryzykując swoim życiem i zdrowiem ${ }^{23}$. W 1956 r. koszt zabiegu w prywatnym gabinecie lekarskim wynosił od 2000-2500 zł, co przy najczęściej otrzymywanej wówczas pensji od 1000-2500 zł było zbyt dużym wydatkiem, zwłaszcza że problem niechcianej ciąży dotyczył głównie kobiet ze środowisk niezamoż-

${ }^{19}$ H. Wolińska, Przerwanie ciąży, s. 15; A. Czajkowska, O dopuszczalności przerywania ciąży. Ustawa z dnia 27 kwietnia 1956 r. i towarzyszace jej dyskusje, s. 137.

${ }^{20}$ H. Wolińska, Przerwanie cią̇̇y, s. 15.

${ }^{21}$ H. Danielak, Ciąża - karą?, „Prawo i Życie” 1958, nr 11, s. 1-2.

${ }^{22}$ Ibidem, s. 2; szerzej zob. A. Czajkowska, O dopuszczalności przerywania ciąży. Ustawa z dnia 27 kwietnia 1956 r. i towarzyszące jej dyskusje, s. $142-143$.

${ }^{23}$ Z. Kubec, Ustawa o warunkach dopuszczalności przerywania ciaży, „Ławnik Ludowy” 1956, nr 6, s. 9; idem, Czy spędzenie płodu jest karalne, „Ławnik Ludowy" 1957, nr 4, s. 12-13; H. Kluźniak, Art. 4 ustawy z 27.IV. 1956 r. o warunkach dopuszczalności przerywania ciąży $w$ świetle akt sądowych ( $\mathrm{Na}$ podstawie materiałów analitycznych Dep. Nadzoru Sądowego), „Biuletyn Ministerstwa Sprawiedliwości” 1963, nr 1, s. 41-42; A. Czajkowska, O dopuszczalności przerywania ciąży. Ustawa z dnia 27 kwietnia 1956 r. i towarzyszace jej dyskusje, s. 142; B. Klich-Kluczewska, Rodzina, tabu i komunizm, s. 241-242. 
nych $^{24}$. Co więcej, źródeł narastania zjawiska niechcianych ciąż po wojnie należało szukać również, a może przede wszystkim, w realiach społeczno-gospodarczych: migracja ludności, rozluźnione więzi rodzinne i dramatyczna sytuacja młodych kobiet w hotelach robotniczych, którą Jacek Kuroń opisał następująco: „Noc w noc trwały hałaśliwe orgie, których przekupiona cerberka nie słyszała. Dziewczyny chodziły w gruzy za parę złotych, za butelkę wina. Mówiono o nich "gruzinki». Oczywiście zachodziły w ciążę, niektóre rodziły, oddawały dzieci do Domu Małego Dziecka. [...] Były liczne przypadki pozbywania się płodu; skrobanka to była wtedy zbrodnia, dziewczyny używały różnych metod, które pamiętały od znachorek wiejskich, chorowały, umierały. Zdarzało się, że rodziły i zabijały dzieci w gruzach”25. Jak ustaliła Barbara Klich-Kluczewska, „kobiety świadomie ryzykowały i nie kontaktowały się z lekarzem, zwykle przeczekując okres powikłań po zabiegu w domu, w ukryciu, $\mathrm{w}$ nadziei na wyleczenie, nawet jeżeli grozić to mogło śmiercią. Nie wychodziły, nie informowały mężów, dzieci czy innych krewnych o przyczynach choroby. Zdarzało się jednak, że ukrywane, a jednocześnie budzące podejrzenia cierpienia wychodziły na jaw już w drodze do domu po zabiegu" ${ }^{26}$.

Kobiety na ogół nie zdawały sobie również sprawy z odpowiedzialności karnej, jaka im groziła. Zwykle były świadome, że kara grozi osobie dokonującej zabieg i dlatego niemal do końca - do śmierci na skutek powikłań - odmawiały jej wskazania ${ }^{27}$.

Jak każde tego rodzaju przepisy, tak i te rozwiązania prawne k.k. z 1932 r. były wyrazem trudnego kompromisu, z czego doskonale zdawano sobie sprawę $\mathrm{w}$ okresie powojennym. Nie przeszkodziło to jednak Helenie Wolińskiej i Jerzemu Sawickiemu w stwierdzeniu, że „zamazywały” one ciężką sytuację materialną wielu ludzi oraz ukrywały właściwą podstawę ekonomiczną obserwowanego wów-

${ }^{24}$ A. Czajkowska, O dopuszczalności przerywania ciąży. Ustawa z dnia 27 kwietnia 1956 r. i towarzyszace jej dyskusje, s. 142.

25 Cyt. za: ibidem, s. 141.

${ }^{26}$ B. Klich-Kluczewska, Rodzina, tabu i komunizm, s. 241-242.

27 Ibidem, s. 242. 
czas zjawiska aborcyjnego ${ }^{28}$. To było bardzo odważne stwierdzenie, zważywszy że podważało ideologiczne fundamenty ówczesnej Polski Ludowej, która tego rodzaju patologiom miała się przecież przeciwstawiać. I chociaż „winę” starano się w pierwszej kolejności „zrzucić” na „burżuazyjny i zamazujący rzeczywistość kodeks”, to jednak w ustroju „sprawiedliwości społecznej” pojawiała się także trudna sytuacja ekonomiczna części matek, które nie było stać na wychowanie dziecka, a nawet na opłacenie fachowej pomocy lekarskiej, niezbędnej przy nielegalnym przerywaniu ciąży ${ }^{29}$. Helena Wolińska przyznała w swojej książce, że Państwo Ludowe nie było jeszcze zdolne, aby poradzić sobie $z$ tego rodzaju zjawiskami, aby je w ogóle wyeliminować, dlatego m.in. niezbędna była nowelizacja przepisów prawa karnego ${ }^{30}$. Starano się zatem zmienić „nadbudowę”, aby zmianie uległa „baza”.

Potrzebna była niewątpliwie reforma. Materiały archiwalne wskazują, że z ramienia Ministerstwa Sprawiedliwości tą problematyką zajął się Jerzy Sawicki. To na jego ręce kierowano adresowane do ministerstwa listy kobiet w sprawie nowelizacji przepisów prawa ${ }^{31}$. Były to niejednokrotnie bardzo wstrząsające obrazy losów kobiet zamężnych, panien i studentek, które będąc w ciąży, znalazły się w bardzo trudnej sytuacji rodzinnej i ekonomicznej ${ }^{32}$. Jak ustaliła Aleksandra Czajkowska, do prasy codziennej napływały również od kobiet listy, których sens był jasny. Sankcje karne nic nie zmienią, jeśli kobiety nie będą mieć warunków bytowych, aby wychować dziecko ${ }^{33}$.

${ }^{28}$ H. Wolińska, Przerwanie ciąży, s. 11 i 15.

29 Z. K., Ustawa o warunkach dopuszczalności przerywania ciąży, „Ławnik Ludowy” 1963, nr 3, s. 16.

30 Z. Kubec, Ustawa o warunkach, s. 10.

${ }^{31}$ Odpis pisma L. Lernella $z$ dnia 25 października 1955 roku do J. Sawickiego w sprawie 29 listów dotyczących problematyki spędzenie płodu (AAN, MS, sygn. 285/1837); B. Klich-Kluczewska, Rodzina, tabu i komunizm, s. 245-250.

${ }^{32}$ Ibidem; podobnie wstrząsające listy napływały wówczas do redakcji czasopism m.in. „Życia Warszawy” i „Przyjaciółki” - zob. szerzej A. Czajkowska, O dopuszczalności przerywania ciąży. Ustawa z dnia 27 kwietnia 1956 r. i towarzyszace jej dyskusje, s. 144-145.

33 „Niech kobieta rozporządza sobą i swoim przyszłym potomstwem. Niech nie będzie tragedii, samobójstw, niech nie giną kobiety z rąk pseudolekarzy. 
Do ministerstwa trafiały też głosy przeciwników liberalizacji przepisów antyaborcyjnych, co wskazywało, że projektowane rozwiązania karnoprawne będą musiały być i tak do pewnego stopnia kompromisowe, w rezultacie niełatwe w każdych warunkach ustrojowych i politycznych. W prace nad projektem zaangażowani byli również Leszek Lernell, Henryk Holder oraz Jan Winiarz ${ }^{34}$.

Efekty prac zostały ujęte w pierwszym projekcie kodeksu karnego Polskiej Rzeczypospolitej Ludowej, ogłoszonym w 1956 r., który od nazwiska jego głównego twórcy określa się w literaturze mianem „Projektu Lernella”35. Na uwagę zasługują dwa przepisy tegoż: art. $131^{36}$ i $132^{37}$. Pierwszy, podobnie jak dotychczasowe uregulowania ujęte w „kodeksie Makarewicza”, traktował jako zasadę zakaz przerywania ciąży. Dostrzegalne jest jednak zastąpienie określenia „płód” (art. 231 i art. 232 k.k. z 1932 r.) pojęciem ciąża, co wskazuje na zmianę przedmiotu ochrony i przedmiotu czynności wykonawczej. „Kodeks Makarewicza” wykorzystywał pojęcie ciąży w przepisie dotyczącym warunków wyłączających bezprawność „spędzenia płodu”, co świadczyło o tym, że w tych okolicznościach pierwszeństwo miało życie i zdrowie kobiety, a nie istnienie płodu. „Projekt Lernella” już takiego rozróżniania nie wprowadzał. Drugi

Każda kobieta pragnie mieć dziecko, ale na to musi mieć warunki. Jeśli ich nie ma, nie pomoże artykuł 231 [kodeksu karnego z 1932 r. - T.Sz.], bo ona znajdzie drogę, aby się ciąży pozbyć - choćby ją to miało życie kosztować” - cyt. za: ibidem, s. 143.

${ }^{34}$ Odpis pisma $z$ dnia 10 kwietnia 1956 roku J. Winiarza do Ministra Sprawiedliwości wraz z notatką (AAN, MS, sygn. 285/1837).

35 Projekt kodeksu karnego Polskiej Rzeczypospolitej Ludowej i przepisy wprowadzajace, Warszawa 1956.

36 „Kto za zgodą kobiety ciężarnej dokonuje zabiegu przerwania jej ciąży, podlega karze pozbawienia wolności do lat 5 (§ 1). Tej samej karze podlega, kto udziela pomocy kobiecie ciężarnej w dokonaniu przez nią samą zabiegu przerwania ciąży" - ibidem, s. 37.

37 „Nie ma przestępstwa określonego w art. 131, jeżeli zabieg był dokonany przez lekarza w zakładzie opieki zdrowotnej zamkniętej i przy tym: 1) za przerwaniem ciąży przemawiają wskazania lekarskie; 2) za przerwaniem ciąży przemawiają wyjątkowo trudne warunki życiowe kobiety ciężarnej, a nie ma przeciwskazań lekarskich; 3) zachodzi uzasadnione podejrzenie, że ciąża powstała w wyniku przestępstwa, a nie ma przeciwskazań lekarskich" (ibidem). 
z proponowanych przepisów projektu wprowadzał warunki wyłączające bezprawność przerywania ciąży. W świetle projektu zabieg ten był dopuszczalny, jeżeli byłby przeprowadzony przez lekarza w zakładzie opieki zdrowotnej zamkniętej oraz zachodziłby jeden z następujących warunków: 1) za przerwaniem ciąży przemawiałyby wskazania lekarskie; 2) za przerwaniem ciąży przemawiałyby wyjątkowo trudne warunki życiowe kobiety ciężarnej, a nie byłoby przeciwskazań lekarskich; 3) zachodziło uzasadnione podejrzenie, że ciąża powstała w wyniku przestępstwa, a nie było przeciwskazań lekarskich ${ }^{38}$.

Powyższa propozycja uregulowania okoliczności wyłączjących bezprawność przerywania ciąży świadczyła dobitnie, że „socjalistyczny ustawodawca" nie zamierzał dalej tolerować zjawiska tzw. pokątnych aborcji, dokonywanych przez osoby bez kwalifikacji medycznych, oraz dostrzegał problemy społeczne matek, które ze względów nie tylko zdrowotnych czy przestępczego pochodzenia ciąży, ale także społecznych, decydowały się na aborcję, bardzo często ryzykując tym samym swoim życiem i zdrowiem. Projektodawcy zrezygnowali $z$ pociągania do odpowiedzialności karnej kobiet, które same dokonałyby przerywania ciąży lub pozwoliłyby na to innej osobie, co jednak nie spotkało się $z$ entuzjazmem. W choćby symbolicznym zagrożeniu karą dla matki dostrzegano środek „odstraszania kobiet od dokonywania zabiegów lekkomyślnie i od korzystania z tańszych "dyskretnych" zabiegów, wykonywanych przez osoby niewykwalifikowane" ${ }^{39}$. Odpowiedzialność karna groziła wyłącznie pomocnikowi (art. $131 \S 2$ ). „Projekt Lernella” nie stał się jednak prawem obowiązującym. Problem karnoprawnej oceny zjawiska aborcji pozostał nierozwiązany, ale nie na długo. Władza ludowa posłużyła się sprowadzonym rozwiązaniem, a więc tzw. kawałkowaną kodyfikacją prawa karnego, czyli regulacją poszczególnych zagadnień w formie odrębnych dekretów (ustaw).

38 Ibidem.

39 M. Lipczyńska, Ochrona płodu, s. 22. 


\title{
3. Ustawa $z$ dnia 27 kwietnia $1956 \mathrm{r}$. o warunkach dopuszczalności
}

\author{
przerywania ciąży
}

Projekt odpowiednich przepisów trafił do Sejmu PRL 12 kwietnia 1956 r., czyli niemal jednocześnie $z$ ogłoszeniem „Projektu Lernella" ${ }^{40}$. W toku burzliwej debaty zgłaszano obawy w związku z ewentualnym przyrostem zjawiska przerywania ciąży i jego negatywnym wpływem na przyrost naturalny ${ }^{41}$. Zwyciężyło jednak przekonanie, że przyrost naturalny nie jest zagrożony, a ponadto, że więcej szkód może wywołać pokątne przerywanie ciąży niż aborcja ze względów społecznych $^{42}$. W konsekwencji ustawą z dnia 27 kwietnia $1956 \mathrm{r}$. o warunkach dopuszczalności przerywania ciąży ${ }^{43}$ dokonano zmiany istniejącego dotychczas stanu prawnego, czyli art. 231-234 k.k. ${ }^{44}$ Oprócz przesłanek dopuszczalności spędzenia płodu określonych w art. 233 k.k. dodano jeszcze jedną, a mianowicie „trudne warunki życiowe kobiety ciężarnej” (art. 1.1 pkt 1b) ${ }^{45}$. Zgodnie z przepisami

${ }^{40}$ Ibidem, s. 20; A. Czajkowska, O dopuszczalności przerywania ciąży. Ustawa z dnia 27 kwietnia 1956 r. i towarzyszace jej dyskusje, s. 146.

${ }^{41}$ Obawy o przyrost naturalny populacji zgłaszano również w toku dyskusji nad projektem kodeksu rodzinnego w latach 1961-1962 w kontekście ustalenia dolnej granicy wieku nupturientów. Problemem dla władzy komunistycznej, podobnie jak w ZSRR, był już nie spadek populacji, ale problemy społeczne związane z jej nadmiernym wzrostem, stąd liberalizacja przepisów aborcyjnych i dyskusja nad zaostrzeniem warunków zawierania małżeństw, w myśl trafnej myśli S. Garlickiego: „nie każda kobieta będzie się decydowała na dziecko w związku pozamałżeńskim" - cyt. za: P. Fiedorczyk, Unifikacja i kodyfikacja prawa rodzinnego $w$ Polsce (1945-1964), Białystok 2014, s. 620-624.

${ }^{42}$ Z. Kubec, Ustawa o warunkach, s. 11; idem, Czy spędzenie płodu, s. 13; szerzej zob. A. Czajkowska, O dopuszczalności przerywania ciąży. Ustawa z dnia 27 kwietnia 1956 r. i towarzyszace jej dyskusje, s. 150-157; B. Klich-Kluczewska, Rodzina, tabu i komunizm, s. 245.

${ }^{43}$ Dz.U. Nr 12, poz. 61.

${ }^{44}$ K. Żmudziński, Luka $w$ przepisach karnych dotyczących ochrony ciąży, „Nowe Prawo” 1958, nr 3, s. 100-102.

${ }^{45}$ Z. Kubec, Ustawa o warunkach, s. 11-12. 
karnymi ustawy kobieta nie ponosiła odpowiedzialności karnej za przerwanie ciąży lub zgodę na dokonanie tego zabiegu. Ponosił ją ten, kto przeprowadził zabieg wbrew przepisom ustawy lub udzielił kobiecie pomocy ${ }^{46}$. Odstąpiono zatem od podejścia „kodeksu Makarewicza” na rzecz propozycji „Projektu Lernella”.

Rewolucyjna zmiana nastąpiła także w pojmowaniu przedmiotu ochrony. Dotychczas było nim życie (istnienie) płodu, natomiast wedle nowej ustawy - zdrowie i życie kobiety ciężarnej ${ }^{47}$. Stąd nie tylko taki tytuł tej ustawy, ale również pojawienie się w jej przepisach karnych - zamiast pojęcia spędzenia płodu - terminu „przerwanie ciąży”, co już zapowiadał „Projekt Lernella”48. Jak przekonywał Włodzimierz Gutekunst, „Przedmiotem ochrony naszego prawa karnego jest tylko życie i zdrowie człowieka, a nie płodu" ${ }^{49}$. Problem jednak w tym, kiedy można mówić „tylko” o płodzie, a kiedy „już” o człowieku, co ma niebagatelne znaczenie nie tylko przy określaniu przedmiotu ochrony/zamachu w przypadku nielegalnej aborcji, ale przede wszystkim dla kwalifikacji czynu jako zabójstwa względnie dzieciobójstwa. Kwestia ta miała charakter kontrowersyjny. Występowały trzy poglądy na ten temat. Pierwszy, wedle którego płód przestaje istnieć $z$ chwilą rozpoczęcia procesu porodowego. Wówczas mamy już do czynienia $z$ dzieckiem (człowiekiem) ${ }^{50}$. Drugi za decydujący uznaje moment oddzielenie się ciała dziecka od ciała matki. Dziecko ma wyjść w całości z łona matki, niezależnie czy oddycha, czy ma samodzielny krwiobieg ${ }^{51}$. Trzeci przyjmował dla odrębności bytów, czyli matki i płodu (dziecka), warunek fizjologiczny w postaci oddechu poza ciałem matki. Jak długo płód oddycha za pomocą

${ }^{46}$ Ibidem, s. 12; Z. Kubec, Czy spędzenie płodu, s. 13; Z. K, Ustawa o warunkach dopuszczalności, s. 17.

${ }^{47}$ H. Wolińska, Przerwanie ciąży, s. 40.

48 Art. 3, 4 i 5 ustawy z 27 kwietnia 1956 roku o warunkach dopuszczalności przerywania ciąży (Dz.U z 1956 r. Nr 12, poz. 61).

49 W. Gutenkunst, Przestępstwa przeciwko życiu i zdrowiu, w: O. Chybiński, W. Gutekunst, W. Świda, Prawo karne - część szczególna, Warszawa-Wrocław 1965, s. 53.

50 Ibidem, s. 56-57.

${ }^{51}$ Ibidem, s. 57. 
krwiobiegu matki, a nie własnych płuc, tak długo nie można mówić, że mamy do czynienia $z$ dzieckiem ${ }^{52}$. Trzeci pogląd dominował.

Niewątpliwie powyższe stanowiska, jak i sama ustawa z 27 kwietnia 1956 r., uderzały w stanowisko Kościoła katolickiego w tym zakresie ${ }^{53}$.

Ustawa o warunkach dopuszczalności przerywania ciąży jednak nie określała ani trybu orzekania o możliwości wystąpienia warunków legalnego przerywania ciąży, ani tego, jakie okoliczności składają się na przesłankę "trudnych warunków życiowych" ${ }^{4}$. W tym zakresie - decydującym o wystąpieniu odpowiedzialności karnej - odsyłała do rozporządzenia wykonawczego ${ }^{55}$. Przepisy tego aktu w istocie oddawały decyzję co do możliwości przerywania ciąży w ręce lekarza, także w przypadku „trudnych warunków życiowych”56. Co więcej, lekarz, który wydał stosowne zaświadczenie, nie mógł wykonać zabiegu. Przepisy nie określały bowiem precyzyjnie, jak ma wyglądać (tryb, dokumenty, zaświadczenia o zarobkach, sytuacji rodzinnej itp.) ustalanie tych warunków środowiskowych przez lekarza i jak się to ma do tajemnicy lekarskiej. Od decyzji odmownej z kolei przysługiwało odwołanie do organu komisyjnego. System zatem, który miał podkreślać dbałość nie tylko o życie i zdrowie kobiety, ale także o jej wolę świadomego macierzyństwa, był w rzeczywistości dysfunkcyjny za sprawą zbyt ramowego charakteru ustawy. Nakładały się na to również problemy światopoglądowe w obrębie środowiska ginekologicznego ${ }^{57}$. Sytuację - przynajmniej na gruncie prawnym - rozwiązało nowe rozporządzenie Ministra Zdrowia $z 19$ grudnia 1959 r. w sprawie przerywania ciąży ${ }^{58}$. Podstawą

52 Ibidem.

53 A. Czajkowska, O dopuszczalności przerywania ciąży. Ustawa z dnia 27 kwietnia 1956 r. i towarzyszace jej dyskusje, s. 161.

${ }^{54}$ Ibidem, s. 158.

${ }_{55}$ Rozporządzenie Ministra Zdrowia z dnia 11 maja 1956 r. w sprawie przerywania ciąży (Dz. U. z 1956 r. Nr 13, poz. 68).

56 A. Czajkowska, O dopuszczalności przerywania ciąży. Ustawa $z$ dnia 27 kwietnia 1956 r. i towarzyszace jej dyskusje, s. 158-160.

${ }^{57}$ H. Wolińska, Przerwanie ciąży, s. 80-81.

58 Rozporządzenie Ministra Zdrowia z dnia 19 grudnia 1959 r. w sprawie przerywania ciąży (Dz.U. z 1960 r. Nr 2, poz. 15). 
przerywania ciąży ze względu na tzw. warunki życiowe miało być od tej pory ustne oświadczenie kobiety o ich zaistnieniu, a zabiegu mógł dokonać ten sam lekarz, który w oparciu o takie oświadczenie wydał orzeczenie o dopuszczalności aborcji ${ }^{59}$. Jeżeli nie zachodziły przeciwwskazania zdrowotne, lekarz był zobligowany do wydania tego rodzaju rozstrzygnięcia (§ 1 i 2 rozp.). Decyzja o przerwaniu ciąży zależała w zasadzie wyłącznie od kobiety ${ }^{60}$.

Według statystyk Departamentu Nadzoru Sądowego Ministerstwa Sprawiedliwości za lata 1958-1961 liczba skazań na podstawie ustawy z 27 kwietnia 1956 r. wahała się między 74 a 108 osób rocznie, choć nie było wątpliwości, że to ułamek całego nielegalnego procederu, który z oczywistych względów uznawano za „trudno wykrywalny" ${ }^{61}$. Wśród skazanych za udział w nielegalnym przerwaniu ciąży dominowały kobiety (90\%), przede wszystkim pielęgniarki, położne, felczerki i tzw. babki62 ${ }^{6}$. Statystyczną pacjentką była $z$ kolei zazwyczaj mieszkanka miasta (70\%), w wieku 20-40 lat (78\%), bez wykształcenia (90\%) i mężatka ${ }^{63}$.

Dla prawa karnego materialnego i przyszłych rozwiązań kodyfikacyjnych w tym zakresie wydanie ustawy z dnia 27 kwietnia 1956 r. oraz rozporządzeń wykonawczych miało niewątpliwie bardzo istotne znaczenie. Uległ zmianie zarówno przedmiot ochrony karnoprawnej, jak i przedmiot czynności wykonawczej ${ }^{64}$. Tym pierwszym było odtąd zdrowie i życie kobiety ciężarnej, a nie płodu. Tym drugim stało się ciało matki, według niektórych proces ciąży, a nie sam

59 Z.K., Ustawa o warunkach dopuszczalności, s. 18.

60 A. Czajkowska, O dopuszczalności przerywania ciąży. Ustawa z dnia 27 kwietnia 1956 r. i towarzyszace jej dyskusje, s. 177-178.

${ }^{61}$ Z.K., Ustawa o warunkach dopuszczalności, s. 41.

62 Ibidem, s. 42.

63 Ibidem, s. 44.

${ }^{64}$ Kwestia określenia przedmiotu ochrony i przedmiotu czynności wykonawczej tej grupy przepisów budziła bardzo wiele kontrowersji. Część doktryny, pomimo wejścia w życie ustawy z 1956 r., uważała, że przedmiotem ochrony jest nadal życie płodu. Odnośnie do przedmiotu czynności wykonawczej większość twierdziła, że jest nim żywy płód, co jednak pozostawało w zgodzie z przekonaniem innych, że jest nim „proces ciąży”, penalizacja zależała bowiem od życia płodu w chwili nielegalnego jej przerywania - szerzej zob. H. Wolińska, Przerwanie ciąży, s. 42-52. 
płód, który należało od tej pory traktować jako element organizmu matki, ewentualnie procesu ciąży ${ }^{65}$. Doktryna prawa karnego PRL i ZSRR była jednak pod tym względem nadal niejednolita, co tylko podkreślało złożoność tej problematyki, na którą składały się nie tylko względy medyczne i prawne, ale także ideologiczne i światopoglądowe ${ }^{66}$.

W prawie karnym pojawiła się także nowa przesłanka wyłączająca bezprawność przerywania ciąży, w postaci „trudnych warunków życiowych". Doprecyzowano także dotychczasową nieścisłość k.k. z 1932 r. odnośnie do przesłanki, że ciąża była wynikiem „przestępstwa”, warunkującej dopuszczalność spędzenia płodu, którą już w okresie międzywojennym wykładano contra legem jako „podejrzenie przestępstwa”, a to w oparciu o treść aktu niższego rzędu, jakim było rozporządzenie ${ }^{67}$.

Wnioski de lege ferenda, jakie wynikały $\mathrm{z}$ uchwalenia i funkcjonowania ustawy z 27 kwietnia, zmierzały znacznie dalej niż zmiana przedmiotu ochrony czy przedmiotu wykonawczego czynu zabronionego przerywania ciąży. W swojej pracy z 1962 r. Helena Wolińska stwierdziła, że w przyszłym kodeksie karnym nie mogą znaleźć się przepisy ustawy z 1956 r., a karalne powinno pozostać jedynie przerwanie ciąży przez osoby niebędące lekarzami oraz bez zgody kobiety ciężarnej68. Innym jej ważnym stwierdzeniem było przekonanie, że prawem karnym nie da się podnieść „kultury współżycia seksualnego". Jedynie podniesienie kultury w ogóle (stopy życiowej, higieny i zdrowia społecznego, świadomego macierzyństwa) może zapobiegać zjawisku przerywania ciąży ${ }^{69}$. Było to ważne stwierdzenie w kontekście okresu 1950-1960, kiedy niewątpliwie panującym poglądem na prawo karne było przekonanie o jego kreacyjnej dla rzeczywistości roli. Wiara, że problem rozwiąże ustawa z 1956 r.,

${ }^{65}$ H. Kluźniak, Art. 4 ustawy z 27.IV.1956 r. o warunkach, s. 45; W. Gutenkunst, Przestępstwa przeciwko życiu i zdrowiu, s. 57.

${ }^{66}$ Cyt. za: H. Wolińska, Przerwanie ciąży, s. 40, przypis 2.

67 Art. 12 ust. 2 rozporządzenia Prezydenta Rzeczypospolitej Polskiej z 25 września 1932 r. o wykonywaniu praktyki lekarskiej (Dz.U. Nr 81, poz. 712).

${ }^{68}$ H. Wolińska, Przerwanie ciąży, s. 125.

${ }^{69}$ Ibidem, s. 127. 
była złudna. Jak jednak zauważyła Helena Wolińska, tego rodzaju przepisy mogą „nieco hamować proceder sztucznych poronień"70.

\section{Problematyka karnoprawna przerywania ciąży według projektu kodeksu karnego z 1963 r.}

Drugi projekt kodeksu karnego materialnego PRL ogłoszony w 1963 r. - nazywany „Projektem Sawickiego” od nazwiska prof. Jerzego Sawickiego, który był jednym $z$ jego głównych referentów również podejmował problematykę karnoprawną przerywania ciąży. W opublikowanym przez Komisję Kodyfikacyjną tekście stypizowano czyny zabronione polegające na: dokonaniu zabiegu przerywania ciąży bez zgody kobiety (art. 203), zmuszaniu kobiety do przerywania ciąży (art. 204) oraz wykonywania zabiegu przerywania ciąży bez wymaganych uprawnień (art. 205) ${ }^{71}$. Pomimo braku w projekcie stanowiska odnośnie do losów ustawy z 1956 r. należy wnosić, że warunki dopuszczalności przerywania ciąży miały pozostać niezmienione. Postulaty de lege ferenda Wolińskiej zostały uwzględnione.

„Projekt Sawickiego”, podobnie jak wcześniej „Projekt Lernella”, upadł. Warto jednak zaznaczyć, że w toku na ogół krytycznej dyskusji nad jego rozwiązaniami nie podejmowano problematyki przerywania ciąży. Słów krytyki w tym względzie nie szczędził za to Episkopat Polski. Dla hierarchów Kościoła katolickiego nie do przyjęcia był art. 203 projektu regulujący przestępstwo przerywania ciąży bez zgody kobiety ${ }^{72}$. A contrario oznaczał on bowiem legalność

70 Ibidem, s. 38.

${ }^{71}$ Projekt kodeksu karnego, Komisja Kodyfikacyjna przy Ministrze Sprawiedliwości, Warszawa 1963, s. 41.

72 „Kto dokonuje zabiegu przerwania ciąży bez zgody kobiety, podlega karze pozbawienia wolności od 6 miesięcy do lat 5 (§ 1). Jeżeli kobieta nie ukończyła 16 lat, prócz jej zgody wymagana jest również zgoda rodziców, opiekuna lub władzy opiekuńczej (§ 2). Jeżeli kobieta, wskutek choroby psychicznej lub niedorozwoju psychicznego, pozbawiona jest całkowicie lub w znacznym stopniu zdolności rozpoznania znaczenia czynu lub kierowania swym postępowaniem, 
przerywania ciąży za jej zgodą. Według Episkopatu takie podejście było sprzeczne nie tylko $z$ prawem naturalnym, ale także zasadami moralności chrześcijańskiej ${ }^{73}$. Jak bowiem podkreślił bp Zygmunt Choromański ${ }^{74}$ : „kobieta ze swojej natury i charakteru powołana jest do tego, by utrzymać rodzaj ludzki. Jest sprzeczne $z$ naturą, by po zajściu w ciążę mogła sama usuwać, przerywać ciążę lub inne osoby do tego upoważniać"75. Był to jasny sygnał, że podejście ustawy z 27 kwietnia 1956 r. było również nie do zaakceptowania ${ }^{76}$, a jedynie słusznym rozwiązaniem były dotychczasowe przepisy „Kodeksu Makarewicza”.

\section{Problematyka karnoprawna przerywania ciąży według kodeksu karnego z 19 kwietnia 1969 r.}

Do karnoprawnej problematyki przerywania ciąży powrócił nowy zespół kodyfikacyjny Ministerstwa Sprawiedliwości powołany w 1964 r. Zespół Prawa Karnego Materialnego miał z tym zagadnieniem poważny problem. Na posiedzeniu w dniu 15 kwietnia 1966 r. Igor Andrejew przedstawił trzy możliwe scenariusze - zdaniem referentów - rozwiązania tej kwestii. Pierwszy: ta problematyka nie byłaby regulowana w kodeksie, a tylko w osobnej ustawie. Drugi: w ko-

zamiast jej zgody wymagana jest zgoda rodziców, opiekuna lub władzy opiekuńczej (§ 3)" - Projekt kodeksu karnego z 1963 roku, s. 41.

${ }^{73}$ Pismo Sekretarza Episkopatu Polski biskupa Zygmunta Choromańskiego z dnia 9 maja 1963 roku do ministra sprawiedliwości Mariana Rybickiego w sprawie uwag do projektu kodeksu karnego, s. 2 (AAN, MS, sygn. 285/564).

${ }^{74}$ Jeden $\mathrm{z}$ trzech sygnatariuszy porozumienia „O niektórych warunkach życia i działalności Kościoła katolickiego w Polsce”, podpisanego 14 kwietnia 1950 r. przez przedstawicieli Kościoła katolickiego i władze komunistyczne A. Nowicz, Stosunki Kościót-Państwo w Polsce 1944-55 (Szkic zagadnienia), Poznań 1984, s. 40-41.

75 Ibidem.

76 A. Czajkowska, O dopuszczalności przerywania ciąży. Ustawa z dnia 27 kwietnia 1956 r. i towarzyszace jej dyskusje, s. 166. 
deksie zostałyby ujęte tylko przepisy karne oraz odesłanie (przepis blankietowy) do ustawy pozakodeksowej, jeśli chodzi o warunki szczegółowe. Trzeci: w kodeksie zostałoby syntetycznie ujęte za pomocą określeń „spędzenie płodu”, „poronienie” lub „zabieg przerywania ciąży" - wszystko to, co dotychczas zawierała ustawa z 27 kwietnia 1956 r. ${ }^{77}$

Igor Andrejew poinformował członków zespołu o tym, że każdy $z$ referentów ma inne zdanie na ten temat, a on uważa, że tak ważnej sprawy nie można pozostawiać poza kodeksem ${ }^{78}$. Odrzucał zatem wariant drugi i trzeci, stawiając na pierwszy. Podobnego zdania byli Jerzy Bafia i Władysław Wolter. Ten ostatni bardzo krytycznie wyraził się o dotychczasowej ustawie oraz rozporządzeniu, zarzucając, że to ostatnie uczyniło $z$ wymogów ustawy fikcję ${ }^{79}$.

Różnice zdań wśród referentów trafnie zdiagnozował Witold Świda, który zauważył, że po prostu nie da się ani całkowicie zerwać $z$ pozakodeksową regulacją, ani wyczerpująco uregulować tego - w znacznej mierze administracyjnoprawnego zagadnienia w kodeksie karnym. Przypomniał członkom zespołu, że nie są kompetentni do ustalania warunków uprawniających przerwanie ciąży, a tylko do ustalania konsekwencji karnych ich naruszenia ${ }^{80}$. Była to aluzja krytyczna pod adresem Igora Andrejewa i Władysława Woltera, którzy byli najwyraźniej skłonni „poprawiać” w kodeksie niedomagania ustawy z 25 kwietnia 1956 r. Propozycja Witolda Świdy stanowiła zatem kolejny - czwarty - wariant, ograniczający regulację kodeksową tylko do przepisów karnych.

Pomimo różnic co do zakresu regulacji kodeksowej wszyscy członkowie zespołu byli zgodni, że warunki dopuszczalności przerywania ciąży mają charakter zmienny i raczej nie powinno się ich wymieniać w kodeksie karnym. Tak też postąpiono.

W uzasadnieniu redakcji projektu po pierwszym czytaniu z $1966 \mathrm{r}$. referenci stwierdzili wprost, że „przepisy ustawy szczególnej z dnia

77 Protokół ZPKM przy MS z dnia 15 kwietnia 1966 r. (K. Kod. 145/82/66), s. 5 - AAN, MS, sygn. 285/1/438.

\footnotetext{
78 Ibidem.

79 Ibidem, s. 7.

${ }^{80}$ Ibidem, s. 9.
} 
27 kwietnia 1956 r. o warunkach dopuszczalności przerywania ciąży nie dają się włączyć w całości do kodeksu”, dlatego zespół zdecydował się w kodeksie rozróżnić spędzenie płodu (art. 150 ${ }^{81}$ projektu z 1966 r.) i zabieg przerywania ciąży (art. $151^{82}$ projektu z 1966 r.), a jeśli chodzi o zasady (warunki) - odesłać do art. 1 i 2 ustawy kwietniowej ${ }^{83}$. Stanowisko to zostało podtrzymane w projekcie z 1968 r., który trafił do Sejmu PRL (art. 159 i 160) (44 $^{8}$.

W uchwalonym następnie 19 kwietnia 1969 r. Kodeksie karnym $^{85}$ karnoprawna problematyka przerywania ciąży została ujęta w art. 153 i $154^{86}$. Okoliczności dopuszczalności przerywania ciąży, a w konsekwencji wyłączające jego bezprawność na gruncie prawa karnego zostały utrzymane poza kodeksem. Był to niewątpliwie rezultat argumentacji Witolda Świdy oraz przekonania większości członków Zespołu Prawa Karnego Materialnego, że to są okoliczności, które mogą ulegać zmianie. Tym sposobem pozostawiono sobie na przyszłość „pole manewru”, zarówno w stronę zaostrzenia, jak i dalszego luzowania warunków dopuszczalności przerywania ciąży, bez zmiany przepisów kodeksu.

81 „Kto przemocą wywołuje poronienia u kobiety ciężarnej albo w inny sposób bez jej zgody spędza płód albo ją do tego zmusza, podlega karze pozbawienia wolności od sześciu miesięcy do lat 5" - Projekt kodeksu karnego. Część szczególna. Wprowadzenie, Warszawa 1966, s. 12.

82 „Kto, wbrew przepisom ustawy, za zgodą kobiety ciężarnej dokonuje zabiegu przerwania ciąży, podlega karze pozbawienia wolności do lat 3 (§ 1). Tej samej karze podlega, kto wbrew przepisom ustawy udziela pomocy kobiecie ciężarnej w dokonaniu zabiegu przerwania ciąży (§ 2)” - ibidem, s. 13.

83 Ibidem, s. 60.

${ }^{84}$ Projekt kodeksu karnego oraz przepisów wprowadzajacych kodeks karny, Warszawa 1968, s. 138; szerzej zob. W. Wolter, Kodeks karny - przestępstwa p-ko życiu i zdrowiu, Zaoczny kurs. Prawo karne - nowe kodeksy, Warszawa 1970 , s. 8-10.

${ }^{85}$ Dz.U. 1969 Nr 13, poz. 94.

86 „Kto przemocą wywołuje poronienie u kobiety ciężarnej albo w inny sposób bez jej zgody przerywa ciążę lub doprowadza ją do tego przemocą, groźbą bezprawną albo podstępem, podlega karze pozbawienia wolności od 6 miesięcy do lat 8” (art. 153); „Kto za zgodą kobiety ciężarnej, lecz wbrew przepisom ustawy, wykonuje zabieg przerwania ciąży, podlega karze pozbawienia wolności do lat 3 (§ 1). Tej samej karze podlega, kto udziela pomocy kobiecie ciężarnej w wykonaniu zabiegu przerwania ciąży wbrew przepisom ustawy (§ 2)” - art. 154. 


\section{Zakończenie}

Prace nad regulacją konsekwencji karnych nielegalnego przerywania ciąży w Polsce Ludowej pokazują dobitnie, że niezależnie od warunków ustrojowych i społecznych jest to jedno $z$ najtrudniejszych zagadnień do uregulowania w prawie. Problem ten ma nie tylko charakter prawny i medyczny, co jest oczywiste, ale przede wszystkim światopoglądowy i ideologiczny. Nie tylko bowiem należy brać pod uwagę ochronę życia i zdrowia matek przed następstwami nielegalnych zabiegów przerywania ciąży, ale również odbiór tego rodzaju zjawiska przez społeczeństwo w określonym układzie społeczno-politycznym. $Z$ tego ostatniego względu kwestia aborcji stanowiła dla władzy ludowej istotny problem. Odmienne od dotychczasowego podejście do przedmiotu ochrony i przedmiotu czynności wykonawczej przy tego typu czynach zabronionych narażały ją na konflikt $z$ Kościołem katolickim i tą częścią społeczeństwa, która wyznawała jego filozofię. Z kolei wprowadzenie „trudnych warunków życiowych" jako jednej z okoliczności uzasadniających legalność przerywania ciąży było dla niej ideologicznie niewygodne. Oznaczało bowiem przyznanie, że w Polsce Ludowej zjawisko pokątnych aborcji ze względów społecznych i bytowych było znaczące, wbrew zapewnieniom, że nowa socjalistyczna „baza” zlikwiduje tego rodzaju zjawiska. Był to również jaskrawy przykład wykorzystania prawa, czyli „nadbudowy”, do kreowania nowej „bazy”, czyli w tym przypadku świadomego macierzyństwa w państwie ludowym. Takie instrumentalne - kreacyjne - podejście do prawa aborcyjnego wpisuje się wyraźnie w mechanizm inżynierii społecznej tego systemu.

\section{STRESZCZENIE}

Problematyka przerywania ciąży

jako zagadnienie kodyfikacyjne prawa karnego materialnego

Polskiej Rzeczypospolitej Ludowej w latach 1956-1969

W pracy przedstawiony został proces kodyfikacji prawa karnego Polskiej Rzeczypospolitej Ludowej w zakresie przestępstwa nielegalnego przerywania 
ciąży. Autor zwrócił uwagę nie tylko na kolejne propozycje ustawodawcze, ale przede wszystkim na ich merytoryczny sens oraz stosunek do norm poprzednio obowiązujących. Artykuł ukazuje podłoże społeczno-polityczne dokonywanych zmian (propozycji) legislacyjnych oraz kontrowersje $z$ nich wynikające. W świetle przeprowadzonych rozważań zagadnienie karnoprawnej oceny przerywania ciąży w PRL jawi się jako problem nie tyle prawny, ile przede wszystkim ideologiczno-polityczny.

Słowa kluczowe: prawo karne; Polska Rzeczpospolita Ludowa; przerywanie ciąży

\section{SUMMARY}

The issue of termination of pregnancy as a codification of substantive criminal law

of the Polish People's Republic 1956-1969

The work presents the process of codification of the Polish People's Republic's criminal law in the field of the crime of illegal termination of pregnancy. The author drew attention to the subsequent legislative proposals and their substantive sense and relationship to the previously applicable standards. The article shows the socio-political background of the legislative changes (recommendations) and the resulting controversies. In the light of the considerations, the criminal law assessment of pregnancy termination in the People's Republic of Poland appears to be not so much a legal problem but primarily an ideological and political one.

Keywords: criminal law; Polish People’s Republic; termination of pregnancy

\section{BIBLIOGRAFIA}

Czajkowska A., O dopuszczalności przerywania ciąży. Ustawa z dnia 27 kwietnia 1956 r. i towarzyszące jej dyskusje, w: Kłopoty z seksem $w$ PRL. Rodzenie nie całkiem po ludzku, aborcja, choroby, odmienności, red. M. Kula, Warszawa 2012.

Czyżewicz A., Częstość poronień, „Polski Tygodnik Lekarski” 1950, nr 12. Danielak H., Ciąża - karą?, „Prawo i Życie” 1958, nr 11.

Fiedorczyk P., Unifikacja i kodyfikacja prawa rodzinnego $w$ Polsce (1945-1964), Białystok 2014. 
Gutenkunst W., Przestępstwa przeciwko życiu i zdrowiu, w: O. Chybiński, W. Gutekunst, W. Świda, Prawo karne - część szczególna, Warszawa-Wrocław 1965.

Klich-Kluczewska B., Rodzina, tabu i komunizm w Polsce 1956-1989, Kraków 2015.

Kluźniak H., Art. 4 ustawy z 27.IV. 1956 r. o warunkach dopuszczalności przerywania ciąży $w$ świetle akt sądowych (Na podstawie materiałów analitycznych Dep. Nadzoru Sadowego), „Biuletyn Ministerstwa Sprawiedliwości” 1963, nr 1.

Kubec Z., Czy spędzenie płodu jest karalne, „Ławnik Ludowy” 1957, nr 4.

Kubec Z., Ustawa o warunkach dopuszczalności przerywania ciąży, „Ławnik Ludowy" 1956, nr 6.

Lipczyńska M., Ochrona płodu w ustawie z 27 kwietnia 1956 r. i projekcie k.k., „Nowe Prawo” 1957, nr 1.

Lityński A., Prawo Rosji i ZSRR 1917-1991, czyli historia wszechzwiązkowego komunistycznego prawa (bolszewików). Krótki kurs, Warszawa 2012.

Makarewicz J., Kodeks karny z komentarzem, Lwów 1938 (reprint Wydaw. KUL 2012).

Nowicz A., Stosunki Kościót-Państwo w Polsce 1944-55 (Szkic zagadnienia), Poznań 1984.

Projekt kodeksu karnego oraz przepisów wprowadzajacych kodeks karny, Warszawa 1968.

Projekt kodeksu karnego Polskiej Rzeczypospolitej Ludowej i przepisy wprowadzajace, Warszawa 1956.

Projekt kodeksu karnego. Część szczególna. Wprowadzenie, Warszawa 1966.

Projekt kodeksu karnego, Komisja Kodyfikacyjna przy Ministrze Sprawiedliwości, Warszawa 1963.

Wolińska H., Przerwanie ciąży w świetle prawa karnego, Warszawa 1962.

Wolter W., Kodeks karny - przestępstwa p-ko życiu i zdrowiu, Zaoczny kurs. Prawo karne - nowe kodeksy, Warszawa 1970.

Z.K., Ustawa o warunkach dopuszczalności przerywania ciąży, „Ławnik Ludowy" 1963, nr 3.

Żmudziński K., Luka $w$ przepisach karnych dotyczacych ochrony ciąży, „Nowe Prawo” 1958, nr 3. 
